\title{
A (IN)APLICABILIDADE DO ARTIGO 156, II, DO CPP NO ÂMBITO DO SUPERIOR TRIBUNAL DE JUSTIÇA A PARTIR DE ANÁLISE JURISPRUDENCIAL
}

\author{
Bruna Vidal da Rocha ${ }^{1}$ \\ Fabiano Manzini ${ }^{2}$
}

Recebido em: 19/11/2019

Aprovado em: 06/02/2020

\begin{abstract}
RESUMO
O presente trabalho consiste em uma pesquisa jurisprudencial realizada no período de 01 de junho de 2014 a 01 de junho de 2015, no âmbito do Superior Tribunal de Justiça, a fim de identificar a (in)aplicabilidade do artigo 156, inciso II, do Código de Processo Penal. O dispositivo citado permite que o julgador produza provas, de ofício, no curso da ação penal, para dirimir eventuais dúvidas. O tema foi abordado sob a ótica do devido processo penal, dos princípios da imparcialidade do julgador, in dubio pro reo, presunção de inocência, verdade real versus verdade processual e demais argumentos utilizados nas decisões.
\end{abstract}

Palavras-chave: Processo penal. Pesquisa jurisprudencial. Imparcialidade. Artigo 156, II, CPP.

\section{INTRODUÇÃO}

Uma das grandes discussões no campo do Direito se encontra na identificação do papel do juiz no Estado Democrático de Direito. Pode-se encontrar diversas respostas para essa pergunta. Alguns diriam que ao juiz, lhe cabe a tarefa de dar a resposta adequada de acordo com o que lhe é apresentado, sem a possibilidade de interferir na causa. Outros diriam que o juiz tem o dever de sair em busca do que chamam de "verdade real" podendo, inclusive, produzir provas para sanar eventuais dúvidas acerca da veracidade dos fatos e das provas que lhe são apresentadas.

\footnotetext{
${ }^{1}$ Mestranda em Direitos Humanos com Bolsa Integral CAPES, Pós-Graduada em Direito Penal e Processo Penal pela Uniritter. Advogada.

${ }^{2}$ Mestrando em Direito Público pela Universidade do Vale do Rio dos Sinos - UNISINOS
} 
Entre essas opções, o que se pode afirmar indubitavelmente é que, ao juiz, lhe cabe julgar. Entretanto, o presente trabalho busca fazer uma reflexão acerca dos limites da atuação desse juiz ao julgar, considerando a imparcialidade, que é um dever de agir do julgador e também a paridade de armas, princípio que prima pela igualdade às partes, quer para a acusação ou para a defesa.

O Código de Processo Penal, em seu artigo 156, inciso II, permite que o juiz produza provas para dirimir dúvidas. Ou seja, permite que o julgador abandone seu papel de espectador e assuma uma postura ativa na produção de provas. Assim, o presente trabalho busca realizar uma pesquisa no Superior Tribunal de Justiça com o objetivo de analisar os julgados que fazem referência à utilização desse dispositivo, demonstrando o posicionamento da Suprema Corte a respeito da sua (in)aplicabilidade e os resultados das decisões em que houve a utilização dessa norma infraconstitucional e, ainda, se houve a reforma dos recursos apresentados pela defesa, ou seja, se a aplicabilidade do artigo se mostra favorável ou não às partes envolvidas.

\section{APRESENTAÇÃO DA PESQUISA}

A presente pesquisa foi realizada no âmbito do Superior Tribunal de Justiça, no período de 01 de junho de 2014 a 01 de junho de 2015, e tem como intuito investigar a (in)aplicabilidade da utilização do artigo 156, II, do Código de Processo Penal e as suas consequências.

A eleição pelo Superior Tribunal de Justiça se justifica por tratar-se de aplicação ou não de um dispositivo infraconstitucional, considerando o Superior Tribunal de Justiça como órgão competente para o resguardo da aplicação da Lei Federal, conforme artigo 105, III, da Constituição Federal (BRASIL,1988). Portanto, caberá ao Superior Tribunal de Justiça afirmar a aplicabilidade ou não do disposto no artigo 156, inciso II, do Código de Processo Penal. Passar-se-á, portanto, à quantificação destes julgados.

A pesquisa foi realizada no site do Superior Tribunal de Justiça, com os termos "156 e II e CPP”, e resultou em 15 (quinze) decisões.

Dessas decisões, 7 (sete) eram Agravos Regimentais nos Agravos em Recursos Especiais, 03 (três) eram Recursos Especiais, 03 (três) eram Recursos em Habeas Corpus, 01 (um) era Agravo Regimental nos Embargos Declaratórios no Agravo em Recurso Especial e 01 (um) era Habeas Corpus. 
Das 15 (quinze) decisões encontradas, 11 (onze) não foram úteis à discussão do presente artigo.

Destas 11 (onze) decisões, 02 (dois) Agravos Regimentais nos Agravos em Recursos Especiais e 01 (um) Agravo Regimental nos Embargos Declaratórios no Agravo em Recurso Especial não foram analisados no mérito, uma vez que não houve pré-questionamento a respeito do argumento de violação ao artigo 156 do Código de Processo Penal (BRASIL, 2015), ou seja, não houve a análise do diploma legal no acórdão recorrido, sendo assim não poderia o Superior Tribunal de Justiça analisá-los em sede recursal.

Das decisões restantes que não serão úteis, foi encontrado 01 (um) Recurso em Habeas Corpus, tão somente pelo fato de constar o número 156 no corpo da decisão. Não importando, assim, à discussão do artigo (BRASIL, 2015).

Das demais decisões, foi encontrado 01 (um) Habeas Corpus no qual não houve alegação de ofensa ao artigo 156 do Código de Processo Penal. O citado dispositivo legal foi utilizado pelo julgador tão somente para fundamentar a decisão de que, por força do artigo 156, caput, do Código de Processo Penal, caberia ao réu comprovar a ausência de potencial lesivo da arma de fogo empregada para intimidar a vítima no crime de roubo (BRASIL, 2015).

Ademais, dentro destas decisões, encontrou-se 01 (um) Agravo Regimental no Agravo em Recurso Especial que alegou a violação ao artigo 156, caput, do Código de Processo Penal, na medida em que a acusação não logrou êxito em comprovar que o acusado comercializava os "produtos ditos objetos de usurpação", e desta forma, como por força do citado dispositivo legal caberia à acusação comprovar o alegado, seria de rigor a absolvição. O julgador afastou a alegação sob o fundamento de que, em verdade, o recorrente apenas estaria, em grau de recurso especial, tentando rediscutir as razões que levaram o Tribunal de origem a proferir um decreto condenatório (BRASIL, 2015).

Neste mesmo sentido, outro Agravo Regimental no Agravo em Recurso Especial alegou ofensa ao artigo 156, caput, do Código de Processo Penal. Entretanto, a alegação foi afastada sob o mesmo argumento de que o recorrente estaria apenas tentando rediscutir as razões que levaram o Tribunal de origem a proferir um decreto condenatório (BRASIL, 2014). Igualmente, mais um Agravo Regimental em Recurso Especial alegou ofensa ao artigo 156, caput, do Código de Processo Penal, no entanto, a alegação foi afastada e sequer amplamente fundamentada (BRASIL, 2014). 
Em outro Agravo Regimental no Agravo em Recurso Especial, o recorrente alegou violação ao disposto no artigo 156 do Código de Processo Penal. Entretanto, a violação foi afastada pelo julgador, na medida em que o recorrente não argumentou os motivos pelos quais os o artigo teria sido violado e a simples alegação de violação não poderia gerar reforma para o ato decisório (BRASIL, 2015).

Em um Recurso Especial encontrado, dois recorrentes alegaram ofensa ao artigo 156, caput, do Código de Processo Penal sob o argumento de que caberia à acusação a comprovação dos fatos imputados por força do citado dispositivo legal e também em virtude da produção antecipada de provas nos autos da medida cautelar. Os recorrentes alegaram parcialidade do julgador e apontaram afronta ao sistema acusatório. O julgador afastou as alegações sustentando que a colheita de provas na medida cautelar não afronta o sistema acusatório e não imprime parcialidade ao julgador. Ademais, o julgador argumentou que um dos recorrentes estaria apenas querendo discutir matéria fática no que concerne ao argumento de que a condenação por lavagem de dinheiro afrontaria o princípio da presunção de inocência, não cabendo ser analisados em sede de recurso especial. Portanto, como não se trata do inciso II do artigo 156 do Código de Processo Penal, a decisão não importa à discussão do trabalho (BRASIL, 2014).

Por último, foi encontrado outro Agravo Regimental no Agravo em Recurso Especial, no qual o recorrente alegou ofensa ao artigo 156 do Código de Processo Penal, entre outros dispositivos do mesmo diploma legal. Foi afastada a alegação do recorrente, pois se assentou em fundamento de índole constitucional suficiente para mantê-lo, o que impede a análise pelo Superior Tribunal de Justiça (BRASIL, 2014).

As decisões acima citadas totalizaram 11 (onze) decisões encontradas pelos termos "156 e II e CPP” que não serão analisadas amplamente, seja por se tratarem do caput do artigo 156 do Código de Processo Penal, seja por não terem sido apreciadas pelo órgão julgador no recurso interposto ou pelos fundamentos até aqui expostos.

Passar-se-á, então, à análise das 04 (quatro) demais decisões pertinentes à pesquisa, ou seja, os posicionamentos das partes envolvidas nos processos, bem como ao exame dos principais argumentos utilizados tanto pelos recorrentes quanto pelos julgadores. Ao final, serão analisados os resultados obtidos no âmbito destas decisões. 


\section{APRESENTAÇÃO DOS RESULTADOS OBTIDOS}

Em primeiro lugar, cumpre relembrar que da pesquisa realizada no Superior Tribunal de Justiça, no período de 01 de junho de 2014 a 01 de junho de 2015, apenas 04 (quatro) decisões são úteis à discussão deste trabalho. Neste ponto, portanto, passar-se-á à análise de cada uma delas.

A primeira decisão a ser analisada se trata de um Recurso Especial (BRASIL, 2014), no qual foi requerida pela defesa a oitiva de duas testemunhas após o prazo estabelecido no artigo 422 do Código de Processo Penal (BRASIL, 1941). Em plenário, o pleito da oitiva de testemunhas foi indeferido por preclusão da decisão. Nas alegações de recurso, a defesa alegou ofensa ao princípio da verdade real, sustentando que, por força do artigo 156, inciso II, do Código de Processo Penal, poderia o julgador deferir a oitiva da testemunha. A preliminar foi afastada sob a alegação de que não houve comprovação de efetivo prejuízo para a acusação ou para a defesa. Assim:

Não configurado o cerceamento de defesa e violação ao disposto no art. 156, II, 209 e art. 497, XI, todos do Código de Processo Penal, em razão do indeferimento, em plenário, da oitiva de duas testemunhas requeridas pela defesa. Na fase de apresentação da contrariedade ao libelo (antiga redação do art. 421 do CPP), a defesa foi intimada para indicar o rol das testemunhas que pretendia ouvir ou requerer diligências, o que foi providenciado, quedando-se, todavia, inerte em pedir a oitiva das testemunhas Edgar Teixeira Sena e Jorge Costa de Souza que agora reputa indispensáveis. Ocorrência da preclusão consumativa (BRASIL,2014).

A alegação da defesa de que o julgador deveria ir em busca da verdade real e deferir a oitiva das testemunhas como se ele mesmo as requeresse nada mais foi do que uma artimanha na tentativa de que as testemunhas fossem ouvidas mesmo depois de precluso o prazo para a apresentação do rol de testemunhas. Cumpre ressaltar que a referida "verdade real" nada mais é do que um mito ilusório, uma vez que no processo penal teremos apenas a verdade processual, que é a verdade reconstruída dentro do processo (LOPES JÚNIOR, 2011, p. 543-544). A busca pela "verdade real" se torna inalcançável porque mesmo que fielmente narrada pelas partes que vivenciaram o acontecimento e até mesmo se reconstruída, o fato é pretérito e não acontecerá exatamente como originalmente se deu.

Igualmente, podemos extrair que o argumento da defesa de que o julgador deveria utilizarse do artigo 156, inciso II, do Código de Processo Penal buscou um juiz inquisidor e totalmente parcial que, se deferisse a oitiva das testemunhas como uma diligência por ele mesmo requerida, estaria optando por ser parcial à defesa e lhe dando a oportunidade de arrolar testemunhas depois 
de precluso o prazo. Da mesma maneira, não restou comprovado prejuízo para a defesa nem para a acusação ao final da decisão, sendo, portanto, afastada a preliminar.

No presente caso, a alternativa viável para a oitiva da testemunha estaria pautada na alegação do princípio da ampla defesa e do devido processo legal, não havendo necessidade de justificar o requerimento com base na busca da verdade real e na utilização do artigo 156, inciso II, do Código de Processo Penal.

A segunda decisão também se trata de um Recurso Especial no qual o réu era acusado pelo delito de estupro. A defesa alegou inconstitucionalidade do artigo 156, inciso II, do Código de Processo Penal por violação ao princípio do acusatório e parcialidade do julgador. Aduziu que o magistrado não poderia, após as alegações finais, de ofício, substituir o órgão acusador e remeter o processo ao Ministério Público para novo aditamento da denúncia acerca da prova da gravidez da vítima, pois o documento não era novo, uma vez que fora incluído no processo antes das alegações finais e, portanto, já estava precluso o direito de aditamento (BRASIL, 2015).

A alegação foi afastada pelo julgador sob o argumento de que a norma que faculta ao juiz determinar de ofício a realização de diligências apenas lhe confere instrumento útil à busca da verdade real e da formação do seu convencimento. Segue trecho do argumento utilizado pela Ministra:

Acrescente-se, por outro lado, que esta Corte de Justiça tem jurisprudência pacífica no sentido de que a norma do artigo 156, inciso II, do Código de Processo Penal, que faculta ao magistrado determinar, de ofício, a realização de diligências, não implica em afronta o princípio acusatório, nem imprime parcialidade ao julgador, apenas lhe confere instrumento útil à busca da verdade real e da formação do seu convencimento (BRASIL, 2015).

Ainda, com relação à preclusão e afronta ao contraditório, afastou tais alegações aduzindo que, diante da prova não contida na denúncia que implica nova definição jurídica ao fato, deve o magistrado admitir o aditamento após a oitiva do defensor do acusado e determinar nova citação, interrogatório e produção de prova em estrita observância à norma do artigo 384 do Código de Processo Penal (BRASIL, 1941).

Desta forma, na decisão, o julgador alegou que em lugar de ser parcial, a medida buscou garantir o contraditório, uma vez que o laudo de DNA fora produzido em interesse da defesa e somente foi objeto de inclusão na imputação após a oitiva do defensor do acusado, tendo sido o réu citado e interrogado novamente, além de deferida a produção de novas provas. Ainda, colacionou julgados no sentido de que a norma contida no artigo 156, inciso II, do Código de Processo Penal 
não afronta o contraditório, mas sim confere ao julgador a posição ativa na instrução criminal, a fim de buscar a formação do seu convencimento, não se confundindo com parcialidade. Assim decidiu:

IX. A possibilidade de o Juiz, nos termos do art. 156, II, do Código de Processo Penal, determinar, de ofício, a juntada de laudo pericial não afronta o sistema acusatório, mas, ao contrário, confere ao julgador posição ativa na instrução criminal, a fim de buscar a formação do seu convencimento, não se confundido, outrossim, com parcialidade.

X. A determinação de diligências, no curso da instrução criminal, a fim de dirimir dúvida sobre ponto relevante, milita em favor da busca da verdade real, princípio basilar do processo penal, não havendo falar em desigualdade entre as partes, já que a diligência requerida pode beneficiar, indistintamente, a acusação ou a defesa (BRASIL, 2015).

Mais uma vez encontra-se como argumento para a fundamentação da decisão do julgador a busca pela verdade real e novamente o argumento de parcialidade utilizado pelo recorrente quando o julgador se utiliza do artigo 156, inciso II, do Código de Processo Penal. Entretanto, cumpre ressaltar a diferença entre a decisão discutida anteriormente e essa, na medida em que restou claro que, na primeira decisão, o recorrente utilizava-se do dispositivo legal como uma artimanha e nesta o julgador utiliza-se do dispositivo para justificar a busca pela verdade real, que mais uma vez relembra-se, é bastante questionável no Processo Penal.

Insta salientar o argumento da defesa de que o dispositivo seria inconstitucional, uma vez que confere posição ativa ao julgador na instrução criminal, trazendo uma atuação inquisitória ao Processo Penal. Assim aduziu a defesa:

Sustenta, nesse passo, a inconstitucionalidade do artigo 156, inciso II, do Código de Processo Penal, que faculta ao magistrado determinar, no curso da instrução, a realização de diligências para dirimir dúvida sobre ponto relevante", por violação ao princípio acusatório (BRASIL, 2015).

A terceira decisão se trata de um Recurso em Habeas Corpus (BRASIL, 2014) com dois recorrentes que foram denunciados por tráfico de drogas, incursos na prática do artigo 33 da Lei 11.343/06 - Lei de Drogas (BRASIL, 2015). Na audiência de instrução para a inquirição das testemunhas comuns da acusação e defesa, não estava presente o Ministério Público. Entretanto, após a inquirição realizada pela defesa, o magistrado optou por prosseguir com o ato, mesmo diante da ausência do Ministério Público, fundamentando sua decisão no artigo 212 do Código de Processo Penal (BRASIL, 1941) e alegando que não haveria prejuízo aos réus. Justificou a 
produção de provas necessárias à formação do seu livre convencimento com base no artigo 156, inciso II, do Código de Processo Penal e na busca da verdade real.

Aduziu não haver prejuízo para os acusados na medida em que o julgador não teria atuado como acusador, mas sim dentro dos limites que lhe são conferidos pelo ordenamento jurídico. Consignou que a testemunha não seria de acusação ou defesa, mas sim do juízo, com a finalidade de buscar elementos para a formação da convicção judicial. Registrou, ainda, que é notória a carência de promotores de justiça na primeira entrância no Estado do Pará e aguardar o comparecimento do órgão ministerial às audiências acarretaria em retardar por tempo indeterminado a duração razoável do processo. Por fim, colacionou jurisprudência no sentido de que a simples ausência do Ministério Público na audiência de oitiva de testemunhas por si só não enseja nulidade, cabendo à defesa comprovar efetivo prejuízo causado ao réu. Assim, segue trecho da ementa recorrida:

Conquanto o Ministério Público não estivesse presente na ocasião em que ouvidas as testemunhas comuns da acusação e da defesa, o certo é que o próprio artigo 212 do Código de Processo Penal permite que o juiz participe das inquirições, sendo-lhe facultada, outrossim, na busca da verdade real, a produção de provas necessárias à formação do seu livre convencimento, nos termos do artigo 156, inciso II, do mencionado diploma legal, o que revela a inexistência do prejuízo suportado pelos acusados, sendo certo que o togado de origem não atuou como acusador, mas dentro dos limites que lhe são conferidos pelo ordenamento jurídico vigente (BRASIL, 1941).

Os recorrentes, por sua vez, sustentam que o julgador tem a função de complementar as inquirições, fiscalizar e controlar, mas não de ser protagonista na colheita dos testemunhos, devendo atuar em posição de espectador e complementar as inquirições quando, ao final, ainda restar dúvida. Requereram fosse anulada a audiência e designada nova data com a presença do órgão ministerial.

O recurso foi improvido sob os seguintes fundamentos:

Da análise dos fundamentos expostos pelo magistrado singular, verifica-se que foram declinadas justificativas plausíveis para a realização do ato instrutório sem a participação da acusação, especialmente o fato de um dos acusados se encontrar preso, não se podendo vislumbrar a ocorrência de eiva apta a contaminar o feito.

Quanto ao ponto, é imperioso destacar que esta Corte Superior de Justiça já pacificou o entendimento de que a simples ausência do órgão acusatório na audiência de oitiva de testemunhas não enseja a nulidade do ato, impondo-se à defesa a comprovação do efetivo prejuízo suportado pelo réu (BRASIL, 1941).

Insta salientar que, para a defesa, a ausência do órgão acusador na audiência e a inquirição das testemunhas por parte do julgador se tratava de nulidade absoluta, uma vez que haveria 
disparidade entre as partes. No entanto, assim como foi demonstrado no trecho da decisão, para os julgadores, a ausência do Ministério Público se tratava de uma simples ausência, atraindo o entendimento pacífico do Superior Tribunal de Justiça de que a nulidade depende da demonstração de efetivo prejuízo o que demonstra que, ao entendimento dos Ministros, a nulidade é relativa (BRASIL, 2014). ${ }^{3}$

Resta claro que, na presente decisão, ocorreu gravíssima atuação do órgão julgador como protagonista na colheita das provas, não cabendo dúvidas com relação à parcialidade do julgador neste momento, uma vez que, diante da ausência da acusação, deveria ter designado nova data para o ato com a presença do órgão ministerial a fim de que houvesse a devida participação de defesa, acusação e órgão julgador imparcial. E mais, a ausência do advogado de defesa nessa mesa audiência acarretaria na suspensão do ato com a designação de nova data. Ausente o Ministério Público, igual deveria ser o entendimento. Entretanto, ainda que se permitisse a continuação da audiência com a ausência do Ministério Público, à defesa, lhe cabe refutar as alegações da acusação. Ausente o Ministério Público, não haveria do que o réu se defender, devendo ser absolvido por força do in dubio pro reo e da presunção de inocência prevista na Constituição Federal. Mas, de forma alguma, deveria o julgador deixar sua posição de espectador e claramente assumir a posição de acusador para realizar perguntas ao réu em substituição às perguntas do membro do Ministério Público.

Ainda, na decisão fora utilizado o argumento de que a audiência teria tido seguimento por um dos acusados se encontrar preso, o que mais uma vez demonstra a inobservância do princípio do in dubio pro reo, pois se inclusive os julgadores necessitavam de respostas para fundamentar sua decisão, o réu sequer deveria estar preso, com base na presunção de inocência. $\mathrm{O}$ ato de inquirição das testemunhas neste caso foi marcado por traços inquisitórios, retornando ao sistema inquisitório vigente antes da Constituição Federal e trazendo forte parcialidade e características inquisitórias ao julgador.

3 Existem diferenças entre a nulidade absoluta e a nulidade relativa. A nulidade absoluta é aquela em que o ato é tão grave que a lei não admite o retorno ao status quo ante. Já na nulidade relativa, não há impedimento de que o ato venha a ser valido novamente, ou seja, não há impedimento de sanar o defeito que torna o ato inválido. A nulidade absoluta pode ser decretada de ofício, independente de manifestação das partes, a qualquer tempo e grau de jurisdição e independe de demonstração de prejuízo, enquanto a nulidade relativa só poderá ser decretada se houver prejuízo efetivo e, ainda, a parte a quem interessa a nulidade poderá abrir mão da formalidade estabelecida em lei. Diferentemente da nulidade absoluta, se a nulidade relativa não for arguida em momento oportuno, haverá preclusão (RANGEL, 2014, p. 948-949). 
A quarta e última decisão se trata de um Recurso em Habeas Corpus (BRASIL, 2015) interposto pela defesa em favor do recorrente que fora denunciado pela prática de peculato, delito previsto no artigo 312, §1º , do Código Penal (BRASIL, 1940). Na fase de alegações finais, o Ministério Público requereu a realização de diligências que, segundo a defesa, teriam mero propósito de corrigir erro constante na denúncia. Entretanto, o julgador acolheu o pedido e deferiu a realização de perícia nas imagens relacionadas ao momento em que o acusado teria escondido o celular subtraído. A defesa não foi intimada dessa decisão e não contribuiu com a prova produzida e, portanto, alegou violação aos princípios da ampla defesa, do contraditório, do devido processo legal, estado de inocência e da duração razoável do processo.

Como fundamentação da decisão do recurso o julgador alega que, embora a defesa sustente nulidade do ato, deixa de apontar qual foi o efetivo prejuízo suportado pelo acusado, atraindo entendimento jurisprudencial pacificado do Superior Tribunal de Justiça de que não há nulidade sem que o ato tenha gerado prejuízo para a acusação ou defesa e, ainda, afirma que o direito ao contraditório foi garantido, pois a defesa pode se manifestar sobre o laudo pericial produzido. Segue trecho do voto:

No entanto, embora alegue a nulidade do ato, a Defensoria deixa de apontar qual o prejuízo que dele teria resultado para a defesa. Ao assim proceder, pugnar pela nulidade do ato sem que demonstre a existência de efetivo prejuízo à defesa, acaba por atrair o entendimento jurisprudencial pacificado desta eg. Corte, no sentido de que "Em matéria de nulidade, rege o consagrado princípio pas de nullité sans grief, segundo o qual não há nulidade sem que o ato tenha gerado prejuízo para a acusação ou para a defesa. Não se prestigia, portanto, a forma pela forma, mas o fim atingido pelo ato. Por essa razão, a desobediência às formalidades estabelecidas na legislação processual só pode acarretar o reconhecimento da invalidade do ato quando a sua finalidade estiver comprometida em virtude do vício verificado, trazendo prejuízo a qualquer das partes da relação processual [...]" (AgRg no AREsp 265.678SP, Sexta Turma, Rel. Min. Rogério Schietti Cruz, DJe de 9/2/2015). Mais do que isso, a hipótese dos autos revela que o direito ao contraditório foi garantido, ainda que de forma diferida, pois a defesa pode, efetivamente, se manifestar sobre o laudo pericial produzido acerca das imagens gravadas. Assim, constatada a existência do direito à impugnação do material probatório juntado aos autos, revela-se destituída de viabilidade jurídica a alegação de nulidade, seja diante da possibilidade do exercício da defesa ampla, seja, ainda, diante da inexistência de prejuízo ao recorrente (BRASIL, 2015). (grifo no original)

Utilizou-se, o julgador, do artigo 156, inciso II, do Código de Processo Penal para sustentar que é facultado ao magistrado, de ofício, a realização de diligências no curso da instrução ou antes de proferir sentença para dirimir dúvida sobre ponto relevante, sendo assim, não haveria que se falar em violação do devido processo legal em virtude do momento processual em que fora deferida 
a realização de perícia. Destacou que a decisão de determinar a diligência observou o princípio da verdade real.

Novamente é possível observar que o dispositivo legal discutido neste trabalho é utilizado com fundamento na busca da verdade real, sendo ignorados os princípios do in dubio pro reo e da presunção de inocência, agindo o magistrado com total parcialidade quando opta por deferir diligência já em fases de alegações finais. Sendo assim, resta claro que o magistrado, optando pela colheita de novas provas, já teria formada sua convicção, buscando em realidade, a condenação, uma vez que a dúvida deveria impor a absolvição (ROSA; KHALD, 2014, p.12).

Das 04 (quatro) análises que foram realizadas dos julgados, podemos concluir que os principais argumentos dos recorrentes foram: cerceamento de defesa, ofensa ao princípio da verdade real, inconstitucionalidade do artigo 156, inciso II, do Código de Processo Penal, violação ao princípio da imparcialidade do julgador, ao princípio da ampla defesa, do contraditório, do devido processo legal, do estado de inocência e da duração razoável do processo. Duas das decisões analisadas argumentaram também violação ao princípio do acusatório.

Com relação às alegações dos Ministros, os principais argumentos utilizados nos 4 (quatro) julgados analisados para afastar as preliminares foram de que a nulidade depende de efetivo prejuízo causado para uma das partes, cabendo a elas a comprovação, não havendo nulidade sem prejuízo. E, ainda, os 04 (quatro) julgados também se utilizaram do argumento de que a norma do artigo 156, inciso II, do Código de Processo Penal, que faculta ao juiz determinar de ofício a realização de diligências, apenas lhe confere instrumento útil na busca da verdade real, não cabendo falar em parcialidade do julgador, mas sim, que ele teria agido dentro dos limites que lhe são impostos pela lei.

Desta forma, tais argumentos representam a importância da discussão deste trabalho, uma vez que estamos ainda em grau de recurso discutindo as principais temáticas de imparcialidade, presunção de inocência, in dubio pro reo e o mito da verdade real, sendo que resta claro que o argumento pela busca da verdade real, que fora utilizado por todos os Ministros nas decisões analisadas vai totalmente de encontro ao que foi exposto nesta pesquisa e aos princípios da presunção de inocência e do in dubio pro reo.

\section{CONSIDERAÇÕES FINAIS}


A presente pesquisa analisou a (in)aplicabilidade do artigo 156, inciso II, do Código de Processo Penal com enfoque no Sistema Acusatório adotado pela Constituição Federal de 1988. Para tanto, buscou-se analisar decisões que referissem a utilização desse dispositivo legal com o intuito de identificar os principais argumentos trazidos pelas partes e pelos julgadores dentro do processo. Para isso, foi necessária a compreensão de princípios como o da imparcialidade do juiz, do in dubio pro reo, da presunção de inocência e da verdade real versus verdade processual.

Com relação aos princípios processuais penais, conclui-se que a imparcialidade do juiz guarda correspondência com o Sistema Acusatório, ou seja, com o papel de espectador do juiz dentro do processo penal, atuando e julgando apenas conforme as provas que lhe são apresentadas, sem que haja um determinado favoritismo para nenhuma das partes envolvidas na relação processual e, ainda, diferenciando imparcialidade de neutralidade, uma vez que juiz neutro não existe, na medida em que no momento de sua decisão, ele opta por um dos lados da relação processual.

Já os princípios do in dubio pro reo e da presunção de inocência guardam correspondência entre si. O princípio do in dubio pro reo se trata de um princípio constitucional que confere benefício para quem se vê acusado de um determinado delito, ou seja, na dúvida, a favor do réu, enquanto o princípio da presunção de inocência possui previsão constitucional explícita no artigo $5^{\circ}$, LVII, da Constituição Federal e estabelece a presunção de não culpabilidade até que haja o transito em julgado da sentença penal condenatória. Sendo assim, possível observar que os dois princípios estabelecem que, em caso de dúvida, o réu deverá ser absolvido.

Com relação aos princípios da verdade real versus verdade processual restou verificado que o processo penal sempre buscou uma verdade mais material e consistente, sendo que o mito da verdade real estaria ligado à estrutura do Sistema Inquisitório, onde haveria a busca por uma verdade a qualquer custo e com a figura do juiz inquisidor. Sendo assim, optou-se por aderir ao termo verdade processual no processo penal.

A verdade processual, portanto, é a verdade trazida para dentro dos autos do processo, é a reconstrução dos fatos de acordo como eles aconteceram e são contados, uma vez que o mito da verdade real seria inalcançável, pois o crime é pretérito, não sendo possível o retorno ao momento em que ele ocorreu. Entretanto, este mito ainda funciona para que sejam aceitas práticas inquisitórias e autoritárias, como restou demonstrado nos julgados analisados. 
Ademais, na pesquisa realizada no âmbito do Superior Tribunal de Justiça, pelo período de 01 de junho de 2014 a 01 de junho de 2015, foi observado que, em realidade, o artigo 156, inciso II, do Código de Processo Penal é utilizado como argumento para a busca da verdade real pelos julgadores, afastando as preliminares que são arguidas pelos recorrentes de parcialidade do julgador na colheita de provas, princípios do in dubio pro reo e da presunção de inocência, trazendo à prática a utilização da verdade real ao invés da busca pela verdade processual do processo penal.

Desta forma, restou demonstrado que o artigo 156, inciso II, do Código de Processo Penal é sim utilizado tanto pelos recorrentes quanto pelos julgadores, em posições contrárias, na qual os recorrentes em sua maioria alegam cerceamento de defesa, ofensa ao princípio da verdade real, a própria inconstitucionalidade do dispositivo legal, ofensa ao princípio da imparcialidade do julgador, da ampla defesa, do contraditório, do in dubio pro reo, da presunção de inocência, da duração razoável do processo e do princípio do acusatório, enquanto os julgadores, em síntese, sustentam não haver nulidade sem efetivo prejuízo comprovado pela parte que alega e que o dispositivo legal infraconstitucional que faculta ao juiz determinar a realização de diligências, em realidade, apenas lhe confere instrumento útil na busca da verdade real, agindo o julgador dentro dos limites que lhe são conferidos pela lei.

O que surpreende, em verdade, é que o dispositivo infraconstitucional é utilizado muito mais pelos julgadores em suas fundamentações do que pelos recorrentes em suas alegações de recurso, ou seja, o dispositivo atribui poderes aos julgadores e eles não hesitam em utilizá-lo.

Assim, o posicionamento majoritário do Superior Tribunal de justiça a respeito da (in)aplicabilidade do artigo 156, inciso II do Código de Processo Penal é de que ele é sim constitucional e portanto, plenamente aplicável, sendo pacífico este entendimento e não havendo discussão a respeito da validade da norma.

O que se pode observar também é que em 100\% dos acórdãos analisados, as preliminares foram afastadas por praticamente os mesmos argumentos, não havendo, em nenhum caso, reforma do ato decisório no que se refere à utilização do artigo, parcialidade do julgador, princípio da verdade real, in dubio pro reo ou princípio da presunção de inocência.

Assim, o presente trabalho teve o intuito de demonstrar os principais argumentos para a utilização desse dispositivo e questioná-los segundo aspectos teóricos, a fim de demonstrar que as alegações dos recorrentes e também dos julgadores representam a importância da discussão deste tema, na medida em que estamos ainda em grau de recurso discutindo as principais temáticas de 
imparcialidade, presunção de inocência, in dubio pro reo e o mito da verdade real. Porém, é possível inferir que embora haja profunda crítica doutrinária a respeito da temática, prevalece o argumento de que o juiz poderá dirimir dúvidas.

Em verdade, o problema todo não está em ser assegurada ou não em Lei a produção de provas pelo julgador, mas sim pelo fato de os julgadores continuarem aplicando o dispositivo sem nenhuma atenção aos princípios já citados. Desta forma, embora a doutrina se questione e exista muitos posicionamentos contrários ao dispositivo, na prática ele é tranquilamente aplicado, inclusive, e principalmente, pelos julgadores.

Como alternativa para esta posição, mais do que a vedação legislativa de existir ou não, deveria ser repensada a postura do julgador diante do dispositivo, pois no momento em que o julgador aceita a produção de provas por parte dele, resta claro que a sua concepção de Sistema processual, de certa forma ainda não está em conformidade com o Sistema essencialmente Acusatório, uma vez que ele assume a postura de produção de provas e não de mero espectador do processo com base no que lhe é apresentado pelas partes.

\section{REFERÊNCIAS}

BRASIL. Constituição (1988). Constituição da República Federativa do Brasil de 1988. Disponível em: http://www.planalto.gov.br/ccivil_03/constituicao/ConstituicaoCompilado.htm. Acesso em 17 de outubro de 2015.

. Decreto-Lei no 2.848, de 7 de Dezembro de 1940. Código Penal. Disponível em: http://www.planalto.gov.br/ccivil_03/decreto-lei/Del2848.htm. Acesso em 17 de outubro de 2015.

. Decreto-Lei no 3.689, de 3 de Outubro de 1941. Código de Processo Penal. Disponível em: http://www.planalto.gov.br/ccivil_03/decreto-lei/Del3689Compilado.htm. Acesso em 14 de outubro de 2015.

. Lei no 5.869, de 11 de Janeiro de 1973. Institui o Código de Processo Civil. Disponível em: http://www.planalto.gov.br/ccivil_03/leis/L5869.htm. Acesso em 17 de outubro de 2015.

. Lei no 11.343, de 23 de Agosto de 2006. Lei de Drogas. Disponível em: http://www.planalto.gov.br/ccivil_03/_ato2004-2006/2006/lei/111343.htm. Acesso em 28 de outubro de 2015.

BRASIL. Superior Tribunal de Justiça. Agravo em Recurso Especial no 436.246. Agravantes: Ministério Público Federal, Rogério Garcia, Nicolas Gouveia Costa de Campos. Agravado: os 
mesmos. Relatora: Ministra Maria Thereza de Assis Moura. Brasília, 06 de maio de 2015. Disponível

em: https://ww2.stj.jus.br/processo/revista/documento/mediado/?componente=MON\&sequencial=475 86718\&num_registro=201303872618\&data=20150511. Acesso em 14 de outubro de 2015.

Agravo em Recurso Especial No 496.028. Agravantes: Everton Henrique de Souza e Genilson Augusto de Souza. Relatora: Ministra Maria Thereza de Assis Moura. Brasília, 25 de setembro de 2014. Disponível em: https://ww2.stj.jus.br/processo/revista/documento/mediado/?componente=MON\&sequencial=349 39178\&num_registro=201400778097\&data=20140930. Acesso em 14 de outubro de 2015.

Agravo em Recurso Especial $n^{\circ}$ 509.409. Agravante: Andre Luis Soares Machado. Agravado: Ministério Público do Distrito Federal e Territórios. Relatora: Ministra Maria Thereza de Assis Moura. Brasília, 31 de outubro de 2014. Disponível em: https://ww2.stj.jus.br/processo/revista/documento/mediado/?componente=MON\&sequencial=411 38083\&num_registro=201401032848\&data=20141105. Acesso em 14 de outubro de 2015.

Agravo em Recurso Especial no 556.480. Agravante: Ministério Público do Estado do Rio Grande do Sul. Agravado: A. C. R. Relatora: Ministra Maria Thereza de Assis Moura. Brasília, 05 de novembro de 2014.2 Disponível em: https://ww2.stj.jus.br/processo/revista/documento/mediado/?componente=MON\&sequencial=415 24948\&num_registro=201401901756\&data=20141110. Acesso em 14 de outubro de 2015.

Agravo em Recurso Especial no 679.993. Agravante: Adriano Pereira. Agravado: Ministério Público Federal. Relatora: Ministra Maria Thereza de Assis Moura. Brasília, 11 de maio de 2015.2 Disponível em: https://ww2.stj.jus.br/processo/revista/documento/mediado/?componente=MON\&sequencial=477 54282\&num_registro=201500666522\&data=20150514. Acesso em 14 de outubro de 2015.

AgRg no Agravo em Recurso Especial no 231.037. Agravante: Rozimar Barrozo de Moraes. Agravado: Ministério Público do Estado de Rondônia. Relator: Ministro Leopoldo de Arruda Raposo. Brasília, 03 de março de 2015. Disponível em: https://ww2.stj.jus.br/processo/revista/documento/mediado/?componente=ITA\&sequencial=1387 314\&num_registro=201201965250\&data=20150311\&formato=PDF. Acesso em 17 de outubro de 2015.

AgRg no Agravo em Recurso Especial no 522.621. Agravante: Ivan Ricardo Lopes de Deus. Agravado: Ministério Público do Estado do Paraná. Relatora: Ministra Maria Thereza de Assis Moura. Brasília, 20 de novembro de 2014. Disponível em: https://ww2.stj.jus.br/processo/revista/documento/mediado/?componente=ITA\&sequencial=1368 103\&num_registro=201401204490\&data=20141212\&formato=PDF. Acesso em 17 de outubro de 2015.

AgRg nos EDcl no Agravo Em Recurso Especial no 484.061. Agravante: Paulo César Bento Inácio. Agravado: Ministério Público Federal. Relatora: Ministra Maria Thereza de Assis Moura. Brasília, 03 de março de 2015. Disponível em: https://ww2.stj.jus.br/processo/revista/documento/mediado/?componente=ITA\&sequencial=1386 
666\&num_registro=201400486556\&data=20150309\&formato=PDF. Acesso em 17 de outubro de 2015.

Habeas Corpus no 305.071. Impetrante: Defensoria Pública Do Estado De São Paulo. Impetrado: Tribunal de Justiça do Estado de São Paulo. Relator: Ministro Gurgel De Faria. Brasília (DF), 28 de abril de 2015. Disponível em: https://ww2.stj.jus.br/processo/revista/documento/mediado/?componente=ITA\&sequencial=1385 921\&num_registro $=201402448073 \&$ data $=20150803 \&$ formato $=P D F$. Acesso em 17 de outubro de 2015.

Recurso em Habeas Corpus $\mathbf{n}^{\mathbf{0}}$ 42.055. Recorrente: Jurandir Bernardo da Silva. Recorrido: Ministério Público Federal. Relator: Ministro Felix Fischer. Brasília (DF), 17 de março de $2015 . \quad$ Disponível em: https://ww2.stj.jus.br/processo/revista/documento/mediado/?componente=ITA\&sequencial=1391 $652 \&$ num_registro $=201303591540 \&$ data $=20150325 \&$ formato $=P D F$. Aceso em 17 de outubro de 2015.

Recurso em Habeas Corpus no 53.470. Recorrentes: José Antonio de Souza Monteiro e Cristalina Gomes Pacheco. Recorrido: Ministério Público do Estado do Pará. Relator: Ministro Jorge Mussi. Brasília (DF), 02 de dezembro de 2014. Disponível em: https://ww2.stj.jus.br/processo/revista/documento/mediado/?componente=ITA\&sequencial=1371 722\&num_registro=201402962502\&data=20141211\&formato=PDF. Acesso em 17 de outubro de 2015.

Recurso em Habeas Corpus $\mathbf{n}^{\circ}$ 54.934. Recorrente: Edgar Bueno de Camargo. Recorrido: Ministério Público do Estado de São Paulo. Relator: Ministro Felix Fischer. Brasília (DF), 17 de março de 2015. Disponível em: https://ww2.stj.jus.br/processo/revista/documento/mediado/?componente=ITA\&sequencial=1391 643\&num_registro $=201403360604 \&$ data $=20150325 \&$ formato $=P D F$. Acesso em 17 de outubro de 2015.

Recurso Especial no 1.440.165. Recorrente: E. L. C. S. Recorrido: Ministério Público do Distrito Federal e Territórios. Relatora: Ministra Maria Thereza de Assis Moura. Brasília, 21 de maio de 2015. Disponível em: https://ww2.stj.jus.br/processo/revista/documento/mediado/?componente=ITA\&sequencial=1410 $088 \&$ num_registro $=201400502235 \&$ data $=20150529 \&$ formato $=P D F$. Acesso em 14 de outubro de 2015 .

. Recurso Especial no 1.170.545. Recorrentes: Axel Ripoll Hamer e outros. Recorrido: os mesmos. Relator: Ministro Nefi Cordeiro. Brasília (DF), 17 de novembro de 2014. Disponível em: https://ww2.stj.jus.br/processo/revista/documento/mediado/?componente=MON\&sequencial $=420$ 23458\&num_registro=200902404509\&data=20141119. Acesso em 14 de outubro de 2015 .

. Recurso Especial $\mathbf{n}^{\mathbf{0}}$ 1.440.787. Recorrente: Jarbas Ferraz Júnior. Recorrido: Ministério Público do Estado do Espírito Santo. Relatora: Ministra Maria Thereza de Assis Moura. Brasília, 07 de agosto de 2014.2 Disponível em: https://ww2.stj.jus.br/processo/revista/documento/mediado/?componente=ITA\&sequencial=1337 
047\&num_registro=201202332946\&data=20140903\&formato=PDF. Acesso em 14 de outubro de 2015.

CARNELUTTI, Francesco. As misérias do processo penal. 5. ed. Campinas: Bookseller, 2004.

LOPES JÚNIOR, Aury. Direito processual penal e sua conformidade constitucional. 8. ed. Rio de Janeiro: Lumen Juris, 2011.

MORAES, Alexandre de. Direito Constitucional. São Paulo: Ed. Atlas S.A, 2003.

RANGEL, Paulo. Direito processual penal. 22. ed. São Paulo: Atlas, 2014.

ROSA, Alexandre Morais da e Khaled Jr, Salah H. In dubio pro hell: profanando o sistema penal. Editora Lumen Juris, Rio de Janeiro, 2014.

\title{
THE (IN) APPLICABILITY OF ARTICLE 156, II, OF THE CPP WITHIN THE SUPERIOR COURT OF JUSTICE FROM JURISPRUDENTIAL ANALYSIS
}

\begin{abstract}
The present work consists of a jurisprudential research carried out from June 1, 2014 to June 1, 2015, in the Superior Court of Justice, in order to identify the (in)applicability of article 156, item II, of the Criminal Procedure Code. The cited article allows the judge to produce evidence, by himself, in the course of criminal proceedings, to resolve any doubts. The subject here was approached from the point of view of the criminal due process, the principles of judge's imparciality, in dubio pro reo, innocence's presumption, real truth versus procedural truth and other arguments used in the analyzed decisions.
\end{abstract}

Key words: Criminal process. Jurisprudential research. Imparciality. Article 156, item II, CPP. 